\title{
Morphometrical and molecular characterization of Bursaphelenchus species from Slovenia
}

\author{
G. UREK, S. ŠIRCA, B. GERIC \\ Agricultural Institute of Slovenia, Plant Protection Department, Hacquetova 17, 1001 Ljubljana, Slovenia, \\ E-mail: gregor.urek@kis.si
}

\begin{abstract}
Summary
The environmental conditions in Slovenia are relatively favourrable for the colonisation and spread of the pine wood nematode Bursaphelenchus xylophilus, a very dangerous pathogenic species which was recently identified in Europe in Portugal. To determine the presence of B. xylophilus in Slovenia and to introduce proper measures against its emergence and spread, a survey of Bursaphelenchus species was conducted in Slovenia from 2002 to 2005. Approximately 120 ha of conifer forests in Slovenia were surveyed for the presence of Bursaphelenchus species. In total, 206 wood samples were taken from the conifer forests. B. hofmanni, B. mucronatus were found for the first time in Slovenia, while B. xylophilus was not detected. Additionally, the species Aphelenchoides stammeri which is morphologically very similar to Bursaphelencus was found. All species have been described morphologically and characterized by ITS-RFLP analysis. Sequences of ribosomal DNA for B. hofmanni, B. mucronatus were analysed.
\end{abstract}

Key words: Bursaphelenchus, Aphelenchoides; nematodes; plant parasitic; pine wood nematode; Slovenia; dissemination; identification; morphological characteristics; DNA characteristics; intraspecific type; internal transcribed spacer; ITS; restriction fragment length polymorphism; RFLP

\section{Introduction}

The damage caused by the pine wood nematode Bursaphelenchus xylophilus (Steiner \& Buhrer) Nickle in several Asian countries, and the ease by which it is spread by the timber trade has provoked scientific interest in tree-inhabiting Bursaphelenchus species. The identification of $B$. xylophilus in Portugal in 1999 (Mota et al., 1999) raised the alarm with regard to the possible presence of this nematode in other European countries. Information concerning the occurrence and distribution of B. xylophilus is very important to assess its potential damage for the forests and economy of a country.

The environmental conditions in Slovenia are relatively favourable for the colonisation and spread of B. xylophilus. Firstly, there is a large area of forest liable to damages and there is sanitary felling of trees due to various pests, pathogenic fungi, storms and fires, especially in the monocultures of Austrian pine in the Karst region. The total forest area in Slovenia consists of 1.227 .832 ha (more than $60 \%$ of the surface of Slovenia is covered by forests), $47.9 \%$ occupied by conifer species, among which four species are dominant: Norway spruce $32.3 \%$, fir $8.1 \%$, Scotch pine $4.7 \%$, Austrian pine $1.2 \%$, and other conifers $1.6 \%$ (Jurc et al., 2003). The second risk factor is the presence of vector insects of the genus Monochamus (Coleoptera: Cerambycidae): M. sartor, M. saltuarius, M. sutor and M. galloprovincialis (Jurc et al., 2003). The third risk factor are the climatic conditions favourable for the development of $B$. xylophilus; it is estimated that Slovenia with the average annual temperature of $10^{\circ} \mathrm{C}$ and the average summer temperature of above $20^{\circ} \mathrm{C}$ in the last few years would be suitable for the colonization and growth of B. xylophilus (Jurc et al., 2003). Therefore, the colonisation and spread of B. xylophilus in Slovenia is very likely and could cause serious difficulties to the Slovenian forest industry (Urek et al., 2004).

The aim of this study was to investigate nematodes of the genus Bursaphelenchus in pine forests and at the entry points for timber imported to Slovenia, especially to determine the potential presence of B. xylophilus in Slovenia, and to introduce proper measures against its emergence and spread.

\section{Material and Methods}

\section{Collecting nematodes}

During the summers of 2002 - 2005, approximately 120 ha 
of conifer forests in Slovenia were surveyed for the presence of the nematodes of the genus Bursaphelenchus. In total, 190 wood samples were taken from conifer forests located in the western part (close to the international harbour of Koper and to the Karst region), central part (the international airport of Ljubljana, close to the village Brnik) and eastern part of Slovenia (close to Kidričevo). Wood samples from dead and dying pines (Pinus sylvestris L., P. nigra Arnold), spruces (Picea abies L.), and firs (Abies alba Miller), predominantly from trees with fungal growth, especially blue stain and the presence of round emergence holes of Monochamus, were analyzed. Trees were sampled by low-speed drill ( $\Phi 13 \mathrm{~mm})$. Sixteen imported coniferous wood consignments were also sampled. Imported wood samples were selected randomly, collected by axe, giving preference to pieces with fungal growth, especially blue stain.

Wood samples were incubated at $+25^{\circ} \mathrm{C}$ in plastic bags for two weeks prior to extraction in Baermann funnels. After 48 hours the water was removed and the nematode suspension was allowed to settle. The suspension was screened for nematodes using a Nikon SMZ 800 stereomicroscope. The specimens belonging to Bursaphelenchus genus were picked out of the suspension for closer investigation. They were killed at $65^{\circ} \mathrm{C}$ and mounted in TAF (Courtney et al., 1955) on microscope slides. Mounted specimens were examined using a Nikon Optophot 2 microscope fitted with Lucia image processing and analysis system. Specimens morphologically identified as genus Bursaphelenchus were subsequently analysed by molecular techniques.

\section{DNA extraction}

Nematode samples (3 to 8 males for each population) were placed in $1.5 \mu \mathrm{l}$ drop of distilled water in $1.5 \mathrm{ml}$ tube and frozen at $-80^{\circ} \mathrm{C}$ until DNA extraction. The samples were thawed and crushed by micropestle. DNA was extracted using the Promega Wizard purification kit according to the manufacturer's instructions. Extracted DNA was diluted in $10 \mu \mathrm{l}$ of distilled water.

\section{PCR amplification and RFLP analysis}

A fragment of rDNA including ITS1 and ITS2 was amplified by PCR and subsequently cut with restriction enzymes to provide intra or interspecies-specific digestion profiles as described previously (Burgermeister et al., 2005). PCR amplification was performed in a total volume of 50 $\mu \mathrm{l}$ using $2 \mu \mathrm{l}$ of DNA extract, $100 \mu \mathrm{M}$ of each dNTP, 0.4 pM of forward primer 5'- CGTAACAAGGTAGCTGTAG3' (Ferris et al., 1993) and 0.4 pM of reverse primer 5'TTTCACTCGCCGTTACTAAGG-3' (Vrain et al., 1992), $3 \mathrm{mM} \mathrm{MgCl}_{2}, 2 \mathrm{U}$ of Taq polymerase (Fermentas) and the corresponding buffer. The amplification was carried out in a Gene Amp PCR system 2700 thermocycler (Applied Biosystems). The PCR protocol started with initial denaturation at $94^{\circ} \mathrm{C}$ for $3 \mathrm{~min}$, followed by 35 cycles of denaturation at $94^{\circ} \mathrm{C}$ for $30 \mathrm{~s}$, annealing at $55^{\circ} \mathrm{C}$ for $45 \mathrm{~s}$ and extension at $72^{\circ} \mathrm{C}$ for $2 \mathrm{~min}$. The reaction was terminated by $10 \mathrm{~min}$ final extension at $72^{\circ} \mathrm{C}$. Amplicons were visua- lised on $1 \%$ agarose. Suitable aliquots of the PCR products were digested with restriction enzymes Rsal, HaeIII, $M s p 1$, Hinfl and Alul and visualised on $2 \%$ gel.

\section{DNA sequencing}

The PCR amplicons of the ITS region were sequenced using both corresponding primers by Macrogen Inc. (Korea). Nucleotide sequences were assembled and analyzed by the computer software Bioedit 5.0.9 (Hall, 1999). Similarity and identity between sequences was analyzed with Blast (Altschul et al., 1997).

\section{Construction of the phylogenetic tree}

The original rDNA sequences and sequences of several Bursaphelenchus species obtained from the NCBI database were aligned using ClustalX 1.83 (Thompson et al., 1997). The phylogenetic tree was constructed by the neighbourjoining method of the bootstrap test using Mega 3.1 software (Kumar et al., 2004).

\section{Results}

In total, 206 wood samples from declining pines (Pinus sylvestris L., P. nigra Arnold), spruces (Picea abies L.), firs (Abies alba Miller) and imported wood samples were analyzed for the presence of Bursaphelenchus spp. B. xylophilus was not found in the area investigated, but other Bursaphelenchus species were isolated from samples of $P$. sylvestris and P. nigra.

Seventy samples of $P$. sylvestris were taken from conifer forests located in the central part of Slovenia, near Brnik, and in the eastern part of Slovenia, close to the town Kidričevo. B. mucronatus Mamiya \& Enda, 1979, was found in five samples; three from the forest near Brnik and two from the forest situated in the vicinity of Kidričevo. Sixtyseven samples of $P$. nigra were collected from plantations in the Karst region, taken from damaged or dead pines. Two of these samples taken from the vicinity of Vrhovlje near Sežana, with visible signs of bark beetle attack, revealed the presence of $B$. hofmanni Braasch, 1998.

Extracted nematodes belonging to the Bursaphelenchus genus were identified morphologically and by the morphometric characters shown in Table 1. Samples of B. mucronatus showed the following morphological characteristics.

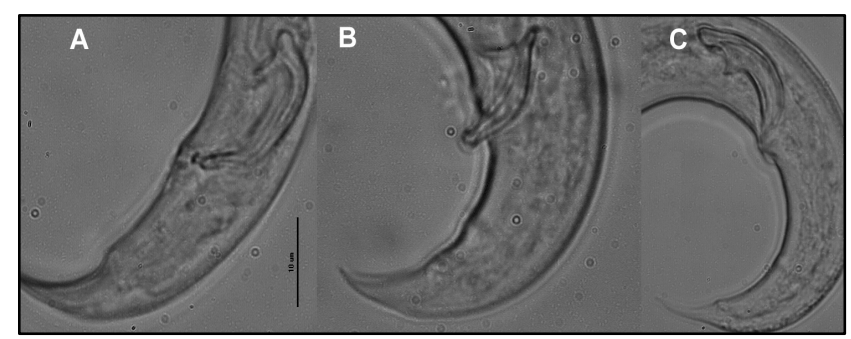

Fig. 1. Photographs of the male tail regions under light microscope. $\mathrm{A}-$ B. mucronatus; $\mathrm{B}-$ B. hofmanni and $\mathrm{C}-$ A. stammeri $(\mathrm{Bar}=10 \mu \mathrm{m})$ 
Table 1. Measurements of B. hofmanni Braasch 1998, B. mucronatus Mamiya \& Enda 1979 and A. stammeri Körner, 1954 populations from Slovenia. Measurements in $\mu \mathrm{m}$ and in form: mean \pm s.d. (range)

\begin{tabular}{|c|c|c|c|c|c|c|}
\hline \multirow[t]{2}{*}{ Characteristics } & \multicolumn{2}{|c|}{$\begin{array}{c}\text { Bursaphelenchus hofmanni } \\
\text { Vrhovlje population }\end{array}$} & \multicolumn{2}{|c|}{$\begin{array}{l}\text { Bursaphelenchus mucronatus } \\
\text { Kidričevo population }\end{array}$} & \multicolumn{2}{|c|}{$\begin{array}{c}\text { Aphelenchoides stammeri } \\
\text { Brnik population }\end{array}$} \\
\hline & female & male & female & male & female & male \\
\hline $\mathrm{n}$ & 10 & 8 & 7 & 8 & 6 & 5 \\
\hline Stylet & $\begin{array}{c}12 \pm 0.8 \\
(10.9-14.0)\end{array}$ & $\begin{array}{c}11.3 \pm 0.6 \\
(10.3-12.2)\end{array}$ & $\begin{array}{c}12.9 \pm 0.7 \\
(12.3-14.0)\end{array}$ & $\begin{array}{c}14.0 \pm 0.8 \\
(12.6-15.0)\end{array}$ & $\begin{array}{c}15.2 \pm 1.0 \\
(14.1-16.5)\end{array}$ & $\begin{array}{c}14.7 \pm 1.4 \\
(13.2-16.6)\end{array}$ \\
\hline $\mathrm{L}$ & $\begin{array}{c}586.7 \pm 49.6 \\
(520.0-663.3)\end{array}$ & $\begin{array}{c}541.0 \pm 44.2 \\
(489.6-621.9)\end{array}$ & $\begin{array}{c}681.5 \pm 66.8 \\
(580.5-769.1)\end{array}$ & $\begin{array}{c}701.6 \pm 70.2 \\
(599.6-787.5)\end{array}$ & $\begin{array}{c}777.7 \pm 98.2 \\
(673.9-905.3)\end{array}$ & $\begin{array}{c}729.4 \pm 53.8 \\
(649.5-790.3)\end{array}$ \\
\hline V\% & $\begin{array}{c}72.0 \pm 0.9 \\
(70.7-73.3)\end{array}$ & - & $\begin{array}{l}71.8 \pm 1.0 \\
(69.7-72.7)\end{array}$ & - & $\begin{array}{c}68.1 \pm 0.6 \\
(66.9-68.5)\end{array}$ & - \\
\hline Body width & $\begin{array}{c}18.8 \pm 1.6 \\
(16.8-22.3)\end{array}$ & $\begin{array}{c}17.1 \pm 1.3 \\
(15.5-18.6)\end{array}$ & $\begin{array}{c}17.7 \pm 0.8 \\
(16.4-19.0)\end{array}$ & $\begin{array}{c}17.0 \pm 1.3 \\
(15.7-19.8)\end{array}$ & $\begin{array}{c}20.3 \pm 2.6 \\
(17.6-24.6)\end{array}$ & $\begin{array}{c}19.7 \pm 2.9 \\
(15.1-22.7)\end{array}$ \\
\hline Tail length & $\begin{array}{c}28.7 \pm 1.6 \\
(27.2-31.9)\end{array}$ & $\begin{array}{c}29.0 \pm 1.9 \\
(26.8-31.9)\end{array}$ & $\begin{array}{c}29.2 \pm 3.6 \\
(22.7-33.4)\end{array}$ & $\begin{array}{c}32.8 \pm 2.8 \\
(29.2-36.5)\end{array}$ & $\begin{array}{c}49.4 \pm 5.3 \\
(44.9-59.8)\end{array}$ & $\begin{array}{c}41.0 \pm 2.4 \\
(39.0-43.6)\end{array}$ \\
\hline Tail width & $\begin{array}{c}8.5 \pm 0.6 \\
(7.5-9.3)\end{array}$ & $\begin{array}{c}11.4 \pm 0.7 \\
(10.1-112.4)\end{array}$ & $\begin{array}{c}9.2 \pm 0.6 \\
(8.2-10.1)\end{array}$ & $\begin{array}{c}12.7 \pm 0.7 \\
(11.6-13.7)\end{array}$ & $\begin{array}{c}12.1 \pm 1.3 \\
(10.5-13.8)\end{array}$ & $\begin{array}{c}12.8 \pm 1.0 \\
(11.2-13.7)\end{array}$ \\
\hline a & $\begin{array}{c}31.5 \pm 3.8 \\
(23.3-36.4)\end{array}$ & $\begin{array}{c}31.7 \pm 3.7 \\
(26.6-38.9)\end{array}$ & $\begin{array}{c}38.5 \pm 4.6 \\
(30.6-43.2)\end{array}$ & $\begin{array}{c}41.3 \pm 3.4 \\
(37.5-48.0)\end{array}$ & $\begin{array}{c}38.3 \pm 2.7 \\
(34.9-42.3)\end{array}$ & $\begin{array}{c}37.4 \pm 3.5 \\
(34.4-43.0)\end{array}$ \\
\hline $\mathrm{c}$ & $\begin{array}{c}20.5 \pm 2.0 \\
(17.8-24.1)\end{array}$ & $\begin{array}{c}18.7 \pm 1.2 \\
(17.1-20.4)\end{array}$ & $\begin{array}{c}23.6 \pm 3.1 \\
(20.4-30.1)\end{array}$ & $\begin{array}{c}21.5 \pm 1.9 \\
(18.8-25.3)\end{array}$ & $\begin{array}{c}15.7 \pm 1.1 \\
(14.5-17.8)\end{array}$ & $\begin{array}{c}17.8 \pm 1.4 \\
(16.3-19.6)\end{array}$ \\
\hline$c^{\prime}$ & $\begin{array}{c}3.4 \pm 0.3 \\
(3.0-3.9)\end{array}$ & $\begin{array}{c}2.5 \pm 0.1 \\
(2.3-2.8)\end{array}$ & $\begin{array}{c}3.2 \pm 0.4 \\
(3.0-3.9)\end{array}$ & $\begin{array}{c}2.6 \pm 0.2 \\
(2.1-2.9)\end{array}$ & $\begin{array}{c}4.1 \pm 0.4 \\
(3.7-4.6)\end{array}$ & $\begin{array}{c}3.2 \pm 0.2 \\
(3.1-3.5)\end{array}$ \\
\hline Spicule* & - & $\begin{array}{c}15.5 \pm 0.6 \\
(15.0-16.6)\end{array}$ & - & $\begin{array}{c}24.6 \pm 1.6 \\
(22.0-27.1)\end{array}$ & - & $\begin{array}{c}20.2 \pm 1.4 \\
(18.1-21.6)\end{array}$ \\
\hline
\end{tabular}

*Spicule measured along curved median line

Female body ventrally arcuate when heat-killed. Lateral field with four incisures. Lip region high, offset. Stylet with small basal thickenings. Vulva posterior, with prominent cuticular flap, ovary outstreched. Tail conoid to a conspicuous digitate terminus. Tail mucro $3-4 \mu \mathrm{m}$ long, with sharply pointed tip (Fig. 1A). Body of male almost J shaped when killed by heat. Anterior region similar to that of female. Spicules paired, massive, strongly arcuate. Condylus bluntly rounded, rostrum prominent and pointed, cucullus present, disc-like. Tail ventrally arcuate, terminus clawlike with bursa. The morphology of examined nematodes corresponded well to the descriptions of Mamiya and Enda (1979). ITS-RFLP analysis of B. mucronatus (Kidričevo population) showed the same restriction patterns (Fig. 2) as described previously for $B$. mucronatus (Burgermeister et $a l ., 2005)$. HaeIII restriction enzyme revealed the European genotype of $B$. mucronatus while Rsal restriction pattern implied the East Asian genotype. Approximate sizes of the ITS-FRLP fragments are shown in Table 2. When the partial rDNA sequence was compared to other known sequences from the NCBI data base, our sequence (acc. no. DQ841162) was most similar to the rDNA sequence of $B$. mucronatus strain DE-4w acc. no. AM179514 with an E value of zero and $99 \%$ identity. The sequence of $B$. $m u$ cronatus (Kidričevo population) clustered with a sequence of B. mucronatus from Germany (AM179514). This was supported by a high bootstrap value (Fig. 3).

Samples of $B$. hofmanni were morphologically identified by the following characteristics (Table 1). Paired, not strongly curved spicules. Condylus almost parallel to the

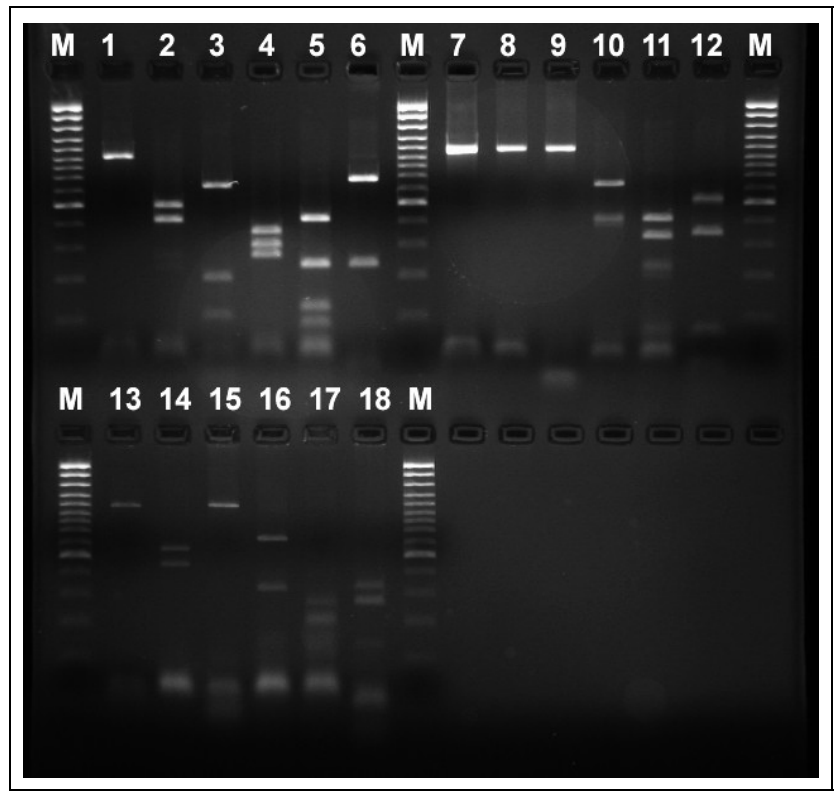

Fig. 2. ITS-RFLP analysis of B. mucronatus, A. stammeri and B. hofmanni revealed descriminatory restriction patterns. Columns $\mathrm{M}$ represent a 100 bp Plus DNA ladder (Fermentas); $1-6 \mathrm{~B}$. mucronatus; 7 - 12 A. stammeri and 13-18 B. hofmanni, undigested amplicon followed by PCR product digested with restriction enzyme Rsal, HaeIII, Mspl, Hinfl and Alul respectively 
Table 2. Approximate sizes of the ITS-RFLP fragments in Bursaphelenchus species and A. stammeri from Slovenia

\begin{tabular}{lcccccc}
\hline \multicolumn{1}{c}{ species } & PCR product & \multicolumn{5}{c}{ Restriction fragments (bp) } \\
\cline { 3 - 7 } & (bp) & Rsal & Haelll & Mspl & Hinfl & Alul \\
\hline B. mucronatus & 950 & 500,410 & $620,220,110$ & $370,310,280$ & $410,250,130,90$ & 700,250 \\
B. hofmanni & 1050 & 560,490 & 1050 & $650,300,130$ & $280,230,150$ & $360,280,150$ \\
A. stammeri & 1050 & 1050 & 1050 & 650,400 & $400,350,230,210$ & $520,460,70$ \\
\hline
\end{tabular}

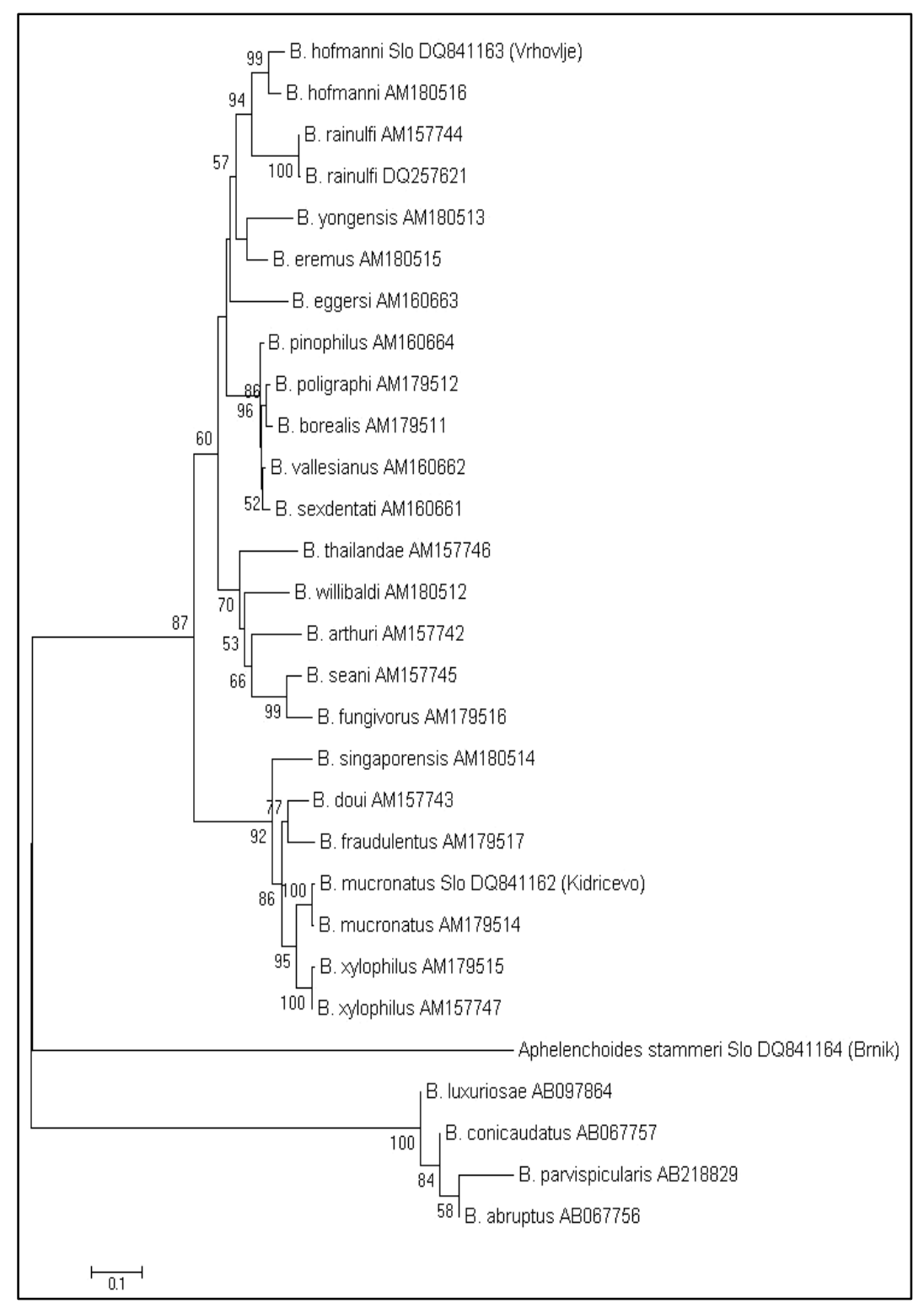

Fig. 3. Neighbour joining tree of Bursaphelenchus spp. and A. stammeri based on their ITS1/2 partial rDNA sequence. Bootstrap values below $50 \%$ are not shown

shaft axis, rostrum prominent and more or less pointed. Distal end of each spicule with cucullus. Male body strongly curved ventrally when heat-killed. Testis outstretched, sometimes reflexed. Tail strongly curved ventrally, conoid, terminus claw-like, with a short terminal bursa (Fig. 1B). Female body curved only slightly when killed by heat. Vulva posterior, the anterior lip modified into a small vulval flap. Reproductive system prodelfic, gonad outstretched, sometimes reflexed. Lateral field with three incisures. Tail conoid and curved, with finely rounded terminus. Anterior body region of female is similar to that of male. Head cap-like, high, without labial annules, 
set off by a distinct constriction. The stylet consists of the usual two parts, the fore part being about one third of the total stylet length and the posterior part without knobs, but with weakly developed basal thickenings.

Molecular characterisation by ITS-RFLP analysis and comparison of the partial rDNA sequence to other known sequences from the NCBI data base indicated B. hofmanni. ITS-RFLP patterns are displayed in Figure 2 and summarized in Table 2. The B. hofmanni sequence (Vrhovlje population, acc. no. DQ841163) was most similar to the rDNA sequence of the $B$. hofmanni strain AT-5w acc. no. AM180516 with an E value of $4 \mathrm{e}-176$ and $90 \%$ identity. Separate clustering with high bootstrap support was shown for the sequences of $B$. hofmanni from the vicinity of $\mathrm{Vr}$ hovlje and B. hofmanni from Austria (AM180516) (Fig. 3). Beside B. mucronatus and B. hofmanni, a few specimens of Aphelenchoides stammeri Körner, 1954, were isolated from a small number of dead Pinus sylvestris trees from the vicinity of Brnik (Table 1). This species is morphologically close to Bursaphelenchus (Braasch, 1998). Extracted specimens were characterised by a body length of 777.7 (673.9 - 905.3) $\mu \mathrm{m}$ in the female and 729.4 (649.5 $790.3) \mu \mathrm{m}$ in the male, relatively robust body $(\mathrm{a}=34.9-$ 42.3 in the female and $34.4-43.0$ in the male). Head caplike, high, without labial annules, set off by a distinct constriction. Stylet $13.2-16.6 \mu \mathrm{m}$ long without knobs, but with weakly developed basal thickenings. Four lines in the lateral field were observed. Characteristic shape of compact, $18.1-21.6 \mu \mathrm{m}$ long spicule without a terminal cucullus. Male tail strongly curved when killed by heat, about two and a half body-widths long, conoid, terminus pointed (Fig. 1C). Female tail 44.9 - $59.8 \mu \mathrm{m}$ long, tapering, ventrally slightly bent. Vulva a transverse slit, vulval flap absent.

The ITS-RFLP profile of $A$. stammeri was determined (Fig. 2, Table 2). Partial rDNA sequence of $A$. stammeri (acc. no. DQ841164) formed a separate clade in the phylogenetic analysis when compared to different Bursaphelencus species (Fig. 3).

\section{Discussion}

The Bursaphelenchus species reported here represent the result of a four years investigation of the presence and distribution of the genus in Slovenia. Clarifying the differences between the species found in Slovenia and the very devastating B. xylophilus is crucial in order to detect the possible presence of the pest. The shape of the spicules of $B$. hofmanni and A. stammeri can easily be distinguished morphologically from $B$. xylophilus. In the case of $B$. mucronatus, the morphological differentiation from B. xylophilus is more difficult but is possible by considering the female tail terminus. The females of $B$. mucronatus have a mucronate tail end whereas $B$. xylophilus females are round-tailed, except for a very small proturbance at the tail end in some individuals from several populations (Braasch \& Braasch-Bidasak, 2002). Consequently molecular identification is indispensable for the differentiation of the two species, particularly when only males or juveniles are found. Molecular identification using ITS-RFLP analyses revealed certain intraspecific variation when comparing ITS-RFLP patterns of B. mucronatus and B. hofmanni from Slovenia with previously published patterns (Burgermeister et al., 2005). While analysis of B. mucronatus (Kidričevo population) with three restriction enzymes does not distinguish between European and East Asian genotype, the patterns of the other two enzymes gave contradictory results, preventing unambiguous identification of the genotype.

B. hofmanni (Vrhovlje population) ITS-RFLP patterns differed from the previously published data (Burgermeister et al., 2005) in four patterns (HaeIII, Mspl, Hinfl and Alul). B. hofmanni (Vrhovlje population) was found in Pinus nigra whereas B. hofmanni from Germany was found in spruce (Burgermeister et al., 2005). However, an intraspecific variation or even the existence of a closely related species of $B$. hofmanni has to be considered for the future, thus further testing of different populations will be needed. The pine wood nematode Bursaphelenchus xylophilus was not discovered in Slovenia whereas the closely related $B$. mucronatus was established in five samples. B. mucronatus has a world-wide distribution in the northern hemisphere and exhibits a high variability between populations (Braasch et al., 1998). The presence of B. mucronatus in Slovenia indicates the possibility of establishment and spread of B. xylophilus, particularly due to the large area of potentially infectable forest in Slovenia, the wide distribution of its host plants (Picea, Pinus, Abies and Larix genus), the wide dissemination of its vectors (Monochamus sartor, M. saltuarius, M. sutor and M. galoprovincialis) and, additionally, the suitable climatic conditions (Urek et al., 2004).

Our study contributes to the knowledge of dissemination of the Bursaphelenchus species, and their morphometrical and DNA characteristics.

\section{Acknowledgements}

This work was supported by the Ministry of Agriculture, Forestry and Food and Ministry of Higher Education, Science and Technology of Republic of Slovenia project no. V4-0461-01.

\section{References}

Altschul, S. F., Madden, T. L., SchäfFer, A. A., Zhang, J., ZhANG, Z., Miller, W., LiPMAN D. J. (1997): Gapped BLAST and PSI-BLAST: a new generation of protein database search programs, Nucleic Acids Res., 25: $3389-3402$

BRAASCH, H. (1998): Aphelenchoides stammeri Körner, 1954 - ein in Deutschland weit verbreiteter Holznematode. Nachrichtenbatt des Deutschen. Pflanzenschutzdienstes, 50: $317-319$

BRAASCH, H. (1998): Bursaphelenchus hofmanni sp. n. (Nematoda, Aphelnchoididae) from spruce wood in 
Germany. Nematologica, 44: 615 - 621

BraAsch, H., Burgermeister, W., Hoyer, U. (1998): Diversity within the species Bursaphelenchus mucronatus worldwide. Proceedings of the $24^{\text {th }}$ International Nematology Symposium, 4 - 9 August 1998, Dundee, Scotland, UK

BRAASCH, H., BRAASCH-BIDASAK, R. (2002): First record of the genus Bursaphelenchus Fuchs, 1937 in Thailand and description of $B$. thailandae sp. n. (Nematoda: Parasitaphelenchidae). Nematology, 7: 853 - 863

Burgermeister, W., Metge, K., BraAsch, H, BuchBACH, E. (2005): ITS RFLP patterns for differentiation of 26 Bursaphelencus species (Nematoda: Parasitaphelenchidae) and observations on their distribution. Russ. J. Nematol., 13: $29-42$

Courtney, W. D., Polley, D., Miller, V. L. (1955): TAF, an improved fixative in nematode technique. Plant Disease Reporter, 39: 570 - 571

FERris, V. R., FERris, J. M. FAGHIHI, J. (1993): Variation in spacer ribosomal DNA in some cyst-forming species of plant parasitic nematodes. Fund. Appl. Nematol., 16: $177-$ 184

HALL, T. A. (1999): BioEdit: a user-friendly biological sequence alignment editor and analysis program for Windows 95/98/NT. Nucl. Acids. Symp., 41: 95 - 98

Jurc, M., UreK, G., ŠIrCA, S., Mikulič, V., Glavan, B. (2003): Pine wood nematode, Bursaphelenchus xylophilus (Steiner \& Buhrer, 1934) Nickle, 1970 - a new threat to forests in Slovenia?. Zbornik gozdarstva in lesarstva, 72: $121-156$

Kumar, S., TAmura, K., NeI, M. (2004): MEGA3: Integrated software for Molecular Evolutionary Genetics Analysis and sequence alignment. Brief. Bioinform., 5: $150-$ 163

MAMIYA, Y., ENDA, N. (1979): Bursaphelenchus mucronatus n. sp. (Nematoda: Aphelenchoididae) from pine wood and its biology and pathogenicity to pine trees. Nematologica, 25: $353-361$

Mota, M. M., BraAsch, H., Bravo, M. A., Penas, A.C., Burgermeister, W., Metge, K., SousA, E. (1999): First report of Bursaphelenchus xylophilus in Portugal and in Europe. Nematology, 1: $727-734$

Thompson, J. D., Gibson, T. J., Plewniak, F., JeanMOUGIN, F. Higgins, D. G. (1997): The ClustalX windows interface: flexible strategies for multiple sequence alignment aided by quality analysis tools. Nucleic Acids Res., 25: $4876-4882$

UreK, G., ŠIrCA, S., JurC, M., JurC, D. (2004): Environmental conditions which could influence the establishment and spread of pine wood nematode in Slovenia. European Society of Nematologists XXVII International Symposium: Rome, 14 - 18 June 2004: programme and abstracts, p. 62 Vrain, T. C., WakarchuK, D. A., Levesque, A. C., HAMILTON, R. I. (1992): Intraspecific rDNA restriction fragment length polymorphism in the Xiphinema americanum group. Fund. Appl. Nematol., 15: 563 - 573 